\title{
Criminal Law Policy Enforcement Against the Perpetrators of Forcibly Picking up the Covid-19 Infected Patient Corpse on This Pandemic at Hospital
}

\author{
Budiyanto \\ Faculty of Law, Cendrawasih University, Papua, Indonesia \\ http://dx.doi.org/10.18415/ijmmu.v8i9.3034
}

\begin{abstract}
This research aims to cover the strategic forms of criminal law policy enforcement to prevent and overcome the covid-19 corpses who were forced picked up in this pandemic at a hospital and its obstacle. The method used in this research is a normative juridical and empirical juridical approach. This research shows that the strategic form of criminal law policy enforcement prioritize more and apply the persuasive approach with negotiation and not using the criminal law policy against the family of the deceased person who forcibly picked and the society which refused to bury the covid1-19 patient. The obstacle faced are: from law substance which not done well on its application; limitation of the security, helplessness of the health officer on facing the pressure and threat, limitation of officer; limitation of facilities and infrastructure which owned by the hospital, police officer, and covid-19 officer (Satgas), the minimum knowledge of the society about the danger of covid-19, minimum of socialization; and the existence of people's habits which not following the strict health protocol, not using a medical mask, and keep a distance.
\end{abstract}

Keywords: Policy; Law Enforcement; Forced Picked up Covid-19 Patient Corpse

\section{Introduction}

The beginning of the Covid-19 pandemic came from Wuhan, Hubei Province, China, in December 2019. WHO have reported the spreading all over the world, including Indonesia. ${ }^{1}$ The Covid-19 outbreak in Indonesia is too late to know when it started and has spread massively. Before the covid-19 outbreak, it had been discovered in Malaysia and Singapore due to the direct flight from Wuhan, China, where the virus originated. After the initial case of Covid-19 has been found by the Indonesian Government, it is considered slow and seemed dismissive as if the Covid-19 would not spread in Indonesia. After the first and second patients identified following with the next patient, the Government became aware of handling the covid19.

Along with the outbreak of Covid-19 spreading around into all areas in Indonesia, there's a problem within this pandemic. Implementing Social Restriction (PSBB), which initially aimed to prevent the spread of the Covid-19 virus, has affected the economy, social aspects, and law enforcement.

\footnotetext{
${ }^{1}$ Haryoto, E., Pambagio, A., \& Wasiat, S,. (2020). Kebijakan Publik Penanggulangan Covid-19. PT. Semesta Rakyat Merdeka. Jakarta. p.1
} 
The real impact has been seen on the small people economy sector. It is caused by the companies that are starting to go bankrupt and out of business, so they choose to close it temporarily, so many employees are eventually laid off. On the social aspect, the increasing number of unemployed people and many residents cannot earn to live, and many of them fall into poverty, resulting in social inequalities that can trigger people to commit crimes and other problems. In addition to the social and economic issues, a problem that is more important on this Covid-19 Pandemic is the problem in criminal law enforcement, both in the form of violations and crimes.

The form of the violation happened on the Social Distancing in several areas, such as not using a mask while riding a bike and ignoring the health protocol. While the form of violation that mostly happened such as drugs, theft, medical devices hoarding (mask, hand sanitizer, antiseptic, disinfectant, rapid test devices, swab test devices, and Personal Protective Equipment), counterfeiting, fraud, embezzlement, corruption and violence in the form of forcibly picking the corpse of the covid-19 infected patient. The police said that nationally, the crime rate increases with the existence of covid-19, which are $19,72 \%$. In February 2020, there were 17.411 cases, and in March 2020, it is raised to 20.845 cases. $^{2}$

In Indonesia, forcibly picking up the infected patient with covid-19 by the family and its relatives is repeatedly happening in some areas. First was happened in Makassar on June 2020 at 3 Hospital, such as RS Labuang Baji, RS Dadi, and RS Stella Maris. ${ }^{3}$ On the other areas, happened on Kolaka (Southeast Sulawesi); West Lombok (West Nusa Tenggara), Tuban, Surabaya (East Java), Rembang (Central Java), Bekasi (West Java) and Ambon (Maluku). In general, the patient who died has the status of ODP (People Under Monitoring), PDP (Patients Under Supervision), ODR (People at Risk), OTG (People Without Symptoms), and is positively infected with coronavirus (Covid-19). In addition to forcibly picking up the bodies of covid-19 patients, there are many cases of rejection of the burial of covid-19 bodies, for example, in Semarang (Central Java) and Mimika (Papua Province) ${ }^{4}$

Given that so far, there are two critical factors: the minimum knowledge of communities about the covid-19 pandemic and the distrust to the Government in making policies and even seen very slow on preventing the spread of this virus. One of the attempts has been made to prevent the forced picking up of the corpse of the dead covid-19 patient with placing several security officers in the hospital. Because some people didn't know and did not care about the dangerous effect of this virus, the reach of this virus is much more difficult. It cannot be abandoned because if the communities already feel hopeless and angry, it is feared that they will act recklessly and take actions outside the control of the law so that later it can endanger the safety and security of the entire community.

This imprisonment threat so far is ignored by the perpetrators. It made the case of forcibly picking up the covid-19 patient corpse still happening until today. Even though there are laws and regulations on the prohibition of forcibly picking up the covid-19 patient corpses with a severe punishment maximum of 7 years, the perpetrators or the family or the communities feel scared/give deterrent effect. Therefore, it is necessary to make more appropriate policies related to the covid-19 pandemic and better efforts. It invites all levels of society to work together to prevent and educate about implementing health protocol rules so that the problem of forcibly picking up the covid-19 corpses can be immediately resolved entirely and minimized.

The focus of this research is to analyze the strategic form of criminal law enforcement policies to prevent and overcome the causes of forced picked up the covid-19 patient corpse during the pandemic in the hospital; and what is the obstacle faced by the hospital officers and police officers in dealing with the perpetrators during the pandemic at the hospital?

\footnotetext{
2 Ridhoi, M., A. (2020, April 22). Kriminalitas Meningkat Selama Pandemi Corona, Sebanyak Apa?Kata Data. https://katadata.co.id/muhammadridhoi/berita/5e9ffbc527b98/kriminalitas-meningkat-selama-pandemi-corona-sebanyak-apa

3 Admin. (2020, June 13). Proses Hukum Pengambil Paksa Jenazah. Media Indonesia. https://mediaindonesia.com/editorials/detail_editorials/2034-proses-hukum-pengambil-paksa-jenazah

4 Tarmizi, T. (2020, April 19). Melihat sisi hukum penolakan jenazah COVID-19. Antaranews. https://www.antaranews.com/berita/1430804/melihat-sisi-hukum-penolakan-jenazah-covid-19
} 


\section{Research Method}

The location of this research is the Local Police of Papua, Jayapura City Police, Provita Hospital, and Dian Harapan Hospital, considering that the related agency is authorized to handle the problems related to Covid-19. A Normative-Juridical approach is used to look at the rules or regulations relating to procedures for handling and burial of the infected covid-19 patient corpses by the task force and hospital officers. While the Juridical-Empirical approach is used to examine the legal action and handling carried out by the police officer and the task force if the forced picking up of the corpses by family or communities have happened. The data analysis in this research used qualitative study in the form of sentence descriptions, which are arranged using a deductive method, namely a way of thinking that starts from general things then conclude specific things. Furthermore, the collected data is arranged systematically in the form of a description of the research report.

\section{Result and Discussion}

\section{The Strategic Form of Criminal Law Enforcement Against the Perpetrators of Forced Picking up the Covid-19 Patient Corpse on This Pandemic at Hospital.}

Since the first covid-19 patient was identified in Indonesia, the Government started a policy to handle and control patients exposed to covid-19. The first step of policy taken by the Indonesian Government began with building the emergency hospital at Galang Island. It is a temporary hospital at the army base of Natuna Island to accommodate the ship crew of Dream Princess from Japan and other ship crew in Sebuku Island, Seribu Islands. The following steps are to import masks, personal protection equipment, ventilator and Polymerase Chain Reaction (PCR) devices. At first, the Government believed can prevent and overcome covid-19 to not spread in Indonesia. But as time changes, the case of covid-19 were spread widely into a cluster in a society.

Since the covid-19 pandemic happened in all areas of Indonesia, the Government started making a covid-19 Officer known as Satgas (Countermeasures Task Force). In line with that, issued several laws and regulation to overcome a problem happened during this pandemic. But, on facing picked up covid-19 patient corpses, there was strategic policy taken by the city police officer of Jayapura and regional police of Papua and the covid-19 officer. Before discussing the strategic form of criminal law policy, then need to explain briefly the chronological of the covid-19 patient corpses picking up which happened in the Jayapura, as follows:

- At first, a patient named MAYUNG ALLO was treated in a hospital at Jayapura, and by the hospital officials, the patient reported died on Friday, July 3 2020, around 5.05 WIT. The hospital's medical personnel will check the sample taken from the dead patient by Swab/PCR to identify covid-19 exposure.

- After that, a guardian from the family of the corpse, which is: IRMA SANDA and ISMAJAYA HARIAWAN, meet the officer of the Provita Hospital, which has been met with the on-duty doctor at the emergency room of Provita Hospital, dr. AYU to take the corpse of the late MAYUNG ALLO, which has been planned, will be buried in the hometown at Makale, Toraja, South Sulawesi.

- The mortuary officer of Provita Hospital explained to the guardian/representative of the family regarding the management of corpses that died with infectious diseases, especially during the covid19 pandemic. Therefore, the mortuary officer did not allow the body to be brought home, that they still had to wait for the result of the swab test to come out. However, it was not approved by the representative and family of the deceased, and the family insisted on forcibly bringing the corpses back to his residence, because according to the belief of the family that the Late MAYUNG ALLO is not favourable for covid-19.

- Because of the pressure from the family then the hospital officer cannot deny, which around 11.30 WIT the family successfully bringing the corpses of the late MAYUNG ALLO to the funeral house at

Criminal Law Policy Enforcement Against the Perpetrators of Forcibly Picking up the Covid-19 Infected Patient Corpse on This Pandemic at Hospital 465 
Baru Putih Bawah RT.003/RW.III South Jayapura for a temporary burial place before the body is sent to its hometown.

- After a few days, the swab/PCR result and the corpses are known for covid-19. Then the Lung Specialist of Provita Hospital, dr. HELENA conveyed to the working group chair for the Acceleration of Handling Covid-19 in Jayapura, dr. NI NYOMAN SRI ANTARI that the late MAYUNG ALLO was declared positive for covid-19.

- On Sunday, July 5 2020, 13.00 WIT. Paur Kesehatan Poliklinik Polres Jayapura, IPTU Z. ASHARI, $\mathrm{SH}$, Amd. Kep. have got an information through a phone from the chair of the working group for the Acceleration of Handling Covid-19 in Jayapura dr. NI NYOMAN SRI ANTARI coordinates with the family, so the corpse of late MAYUNG ALLO is buried with the health protocol.

- 16.45 WIT, member of URC of COVID-19 of Jayapura which headed by Paur Kesehatan Poliklinik Polres Jayapura IPTU Z. ASHARI, SH, Amd, Kep. Arrived at funeral house at Batu Putih Bawah RT 003/RW III South Jayapura, then the member of URC Covid-19, Police of Jayapura starting using the Personal Protection Equipment.

- 17.00 WIT, Paur Kesehatan Poliklinik Polres Jayapura IPTU Z. ASHARI, SH, Amd, Kep coordinate with the family which are Ms. IRMA SANDA and Mr. ISMAYA HARIAWAN to buried the corpses with health protocol.

- 17.45 WIT, a member of URC Covid-19, Jayapura Police, carried out the process of wrapping the coffin of the late deceased MAYUNG ALLO using plastic.

- 18.00 WIT the wrapping process of the coffin of the late deceased MAYUNG ALLO by the URC Covid-19 members have done then the short worship and prayer led by Mr. DANIEL.

- 18.20 WIT the member of URC Covid-19, Jayapura Police, take out the corpse of the late MAYUNG ALLO from the funeral home to the URC Covid-19 Ambulance Car to be buried under the health protocols

- 18.30 WIT, a spontaneous protest by a local resident regarding the rejection of the funeral of the late deceased MAYUNG ALLO according to health protocol.

- 18.35 WIT, the members of Regional People's Representative Assembly of Jayapura SARCE SORRENG arrived at the funeral house and at immediately protested against the Jayapura City Police URC Covid-19 team. He then asked for an official letter from the Jayapura City Covid-19 Handling Acceleration Task Force Team related to the statement that the body of the late MAYUNG ALLO tested positive for Covid-19.

- 18.40. WIT, the member of URC Jayapura Police headed by Paur Kesehatan Poliklinik Polres Jayapura IPTU Z. ASHARI, SH, Amd, Kep. Giving back the corpse to the family for the late MAYUNG ALLO to be buried at the funeral houses.

- 21.40 WIT, URC Team Unit 1 of the Aman Nusa II, the police of Papua under the lead of IPTU Hasan Basri arrived at the funeral house at Batu Putih Jayapura, South Jayapura, and finally negotiated with the family and the communities around 30 minutes, and successfully evacuate the corpse of the covid19 patient, the late MAYUNG ALLO, 63 years old, and went to the buried place special for Covid-19 victims Jayapura (Bumper Waena) ${ }^{5}$

According to the chronological above, the source of the problem came from the late result of the swab test delivered to the late deceased family. If only the swab test result could be faster, then the misunderstanding would not happen, and there will be no forced picking up the corpse and rejection of funerals according to health protocols. The explanation delivered by the hospital officer cannot convince the late family because the result of Swab/PCR is still not finished. Even after the outcome are in, the family won't believe the result and still believe that the late deceased are not infected with Covid-19.

The information of the corpse, which is positive, seems heard by the resident around the deceased. Therefore, the resident planned to block the road and closed the entrance and exit. It would not carry the bodies through the road. Residents are afraid of contracting with Covid-19 if the bodies are carried out through the street. The Jayapura City Police and the Covid-19 Task Force members are trying hard to make

${ }^{5}$ Kamaluddin, (2020, September 21). Personal Interview 
various efforts and policies. According to the interview with Kompol Philip M. Ladjar, S.H, the task force of Gakkum Ops Aman Nusa II Matoa Regional Police of Papua, the move was taken on handling or dealing with this incident which using persuasive approach with negotiating and giving an understanding to the family and resident about the spread of covid-19 virus hence the corpsed should be buried under health protocol. $^{6}$

Therefore, the persuasive approach with negotiation (preventive measures) is to choose to face the family and the resident, which will close the road and law enforcement (repressive measures). After the police and the covid-19 officer also the hospital gave a detailed explanation and showing the test result issued by Provita Hospital, then, in the end, the family could accept and understand the condition that happened. The family receives and allows the late corpse to be buried under the health protocol.

After dealing with the family, the police officer performs a persuasive effort with the resident, closing the road. A detailed explanation and procedures of handling the corpse infected with covid-19 have been put into a water-resistant coffin, wrapped with plastic, and placed on the coffin. The coffin is then covered under the standard procedure (WHO Policy) so that the virus will not spread to the resident if they pass the road that will be closed. In the end, the resident can be calmed down and understood so that the resident agreed to open the road for the hearse to pass the road. In the burial place, it must prioritize the safety and health of everyone near the body. They must pay attention to hand hygiene, distance from bodies and distance between individuals, and using personal protective equipment. In the end, the corpse's funeral can go well and according to the covid-19 funeral procedures.

The form of strategic policy taken by the police officer of Jayapura and the officer of Gakkum Ops Aman Nusa II Matoa Papua Regional Police in the form of persuasive approach policy can be seen as an exact action. The primary consideration is that every step from the family of the late deceased or the communities around the house of the late is seen under the laws and regulations. Although initially, the family and communities refused to bury the late dead under the covid-19 protocols. Still, in the end, the family and communities agreed to follow the explanation from the officers and were willing to follow the laws and regulations. Therefore, it can be inaccurate if the officer chooses to use the criminal law policy enforcement, although no one violates the law. It means that the persuasive approach policy is more considered rather than using the criminal law policy enforcement. If it referred to the law enforcement, then it can be quoted from Syukri Akkub and Baharuddin Badaru as quoted by Budiyanto ${ }^{7}$ interpreted as a process of carrying out an effort to enforce or functioning a legal norm in a real way as a behavioural guide in traffic or relationship in social and patriotic life. ${ }^{8}$ It means that the perpetrators will be processed until submitted into court trial. But in reality, what law enforcers have done is not aimed at punishing the perpetrators but instead using a family approach by providing explanation and calm to the victim's family and the surrounding community.

The case of rejection of the burial of the covid-19 corpse has also happened before in April 2020, where there we dozens of residents of the Kompleks Bunda Maria at Bumper Waena, Haram District, Jayapura. The resident was rejecting the burial of the covid-19 corpse at the Muslim public cemetery at Bumper Waena. The resident refuses because there is no announcement and socialization to the resident who will bury the corpse of the covid-19 patient at Bumper Waena. Other than that, the resident felt worried that they would be infected if the corpses were buried near their resident. But, the head of the health department of Jayapura, Ni Nyoman Sri Antari, successfully explained to the resident that the burying of covid-19 corpses had been sterilized and under the WHO Standard so that the resident shouldn't be worried to be infected.

Criminal law policy enforcement can be done if so many persuasive attempts such as mediation and negotiation have been made, but not successful, and going into a situation of security disturbance in

\footnotetext{
${ }^{6}$ Ladjar, P.M., (2020, September 21). Personal Interview

${ }^{7}$ Budiyanto. (2017). Revitalisasi Peradilan adat Sebagai Alternatif Penyelesaian Delik Adat Pada Masyarakat Hukum Adat Papua. Intelegensia Media. Malang. p. 70-71

${ }^{8}$ Akub, S. \& Badaru, B,. 2013. Wawasan Due Process of Law Dalam Sistem Peradilan Pidana. Rangkang Education. Yogyakarta. p. 20-21
} 
society. Therefore, related to the perpetrator of forcibly picking up the corpse of the covid-19 patient, according to the criminal code, it can be categorized into a crime against the Common Powers, which are Article 212-216 of the criminal code. Article 212 of Criminal Code with an imprisonment threat for one year and four months, Article 214 of Criminal code with an imprisonment threat for seven years, and 216 of criminal code with imprisonment threat for four months and two weeks. Other than that, Article 14 of The Law No. 4 of 1984 concerning of Infectious Disease Epidemic with the imprisonment threat for one year and fines as high as 1 million, Article 93 of the Law No. 6 of 2019 Concerning Health Quarantine, with imprisonment threat for one year or fines as high as 100 million. According to the interview, it is known that taking the law enforcement policy taken by the police officer of Jayapura and Papua Regional Police related to the Covid-19 must be guided by the police headquarter. Therefore, in handling covid-19, police have done an Ops Aman Nusa II-2020, which are centralized. ${ }^{9}$

The involvement of the Police of Jayapura and Papua Regional Police in handling the covid-19 pandemic based on: (1) Regulation of the Chief of the Indonesian National Police No. 1 of 2019 Concerning of Police Management System and Operational Success Standards; (2) Papua Governor Decree No. 188.4/121 of 2020 concerning of the Establishment of the Covid-19 Infection Prevention Task Force; and (3) Renops Aman Nuda II Matoa-2020 No. R/RENOPS/2/III/OPS.2./2020 of March 19, 2020, concerning Acceleration and Anticipation of the Impact of the 2020 Corona Virus Disease (COVID-19) Outbreak in the Papua Regional Police Legal Territory.

In facing the case of forcibly picking up the corpse of the covid-19 infected patient and the refuse of burying the infected covid-19 corpse in Jayapura, the officers of Aman Nusa-II Regional Police of Papua worked together with the related agency in the form of verbal coordination, such as communication between hospital and task force (which now has been changed into Covid-19 Task Force) also the PRC unit of Aman Nusa-II Regional Police of Papua Task Force to do the burial of the corpse smoothly under health protocol. The Government of Jayapura, according to the Ministry of Internal Affairs letter, have made an adjustment and the establishment of Covid-19 Taskforce and disband the task force.

According to the result of the study which has been done, it revealed that the form of strategic policy taken by the Government of Jayapura related to the covid-19 handling is (1) the implementation of social distancing, (2) implementation of sanction, and (3) a policy to following a strict health protocol (must use mask). Those three policies aimed to reduce the spread of covid-19 viruses in the communities, especially at Jayapura.

According to the condition in the field, those three forms of policies from the Jayapura government in the implementation isn't that effective. Some people are still not disciplined and don't have a high awareness to following the health protocol by using the mask, keep a distance (It is forbidden to gather especially in events, for example weddings, birthdays, to recreational areas and other activities), and the sanction implementation such as social sanction and even fines toward the communities which are raided by not using a mask. The form of violation related to the covid-19 by the communities, the gym still chosen as a placed to gather without using the mask or using the mask but the inappropriate way and not keep a distance between people. Therefore, it is necessary to have a strategic form of law enforcement policy that is firm, precise, and immediately implemented so that the violations can be prevented and minimized.

It must implement the strategic form of criminal law enforcement against the perpetrators of forcibly picking up the bodies of the patients infected with covid-19 at the hospital during the pandemic indiscriminately. Because it will be too late if it turns out that later the corpse that has been forcibly taken and brought to the house turns out infected with covid-19 as happened. Of course, the impact that occurs is that relatives and those who have physical contact with the infected bodies are likely to be infected. Therefore. This action must be taken immediately against those in physical contact to do a swab/PCR test to find out whether they have been infected or not. However, if some are not accessible for inspection and they gather with other family members, it will increase the chance of difficulties to detect the spread.

${ }^{9}$ Op. Cit. Ladjar, P.M. 


\section{Obstacle Faced by the Hospital Officer and Police Officer Against the Perpetrators of Forcibly Picking up the Covid-19 Infected Corpse in this Pandemic at Hospital}

According to the result of a study which has done, it is revealed that the obstacle faced related to the forcibly picking up the covid-19 infected corpsed in this pandemic at the hospital are:

1. The obstacle in terms of legal substances related to Covid-19 which still overlap in its implementation such as, Article 14 of Law No. 4 of 1984 Concerning of Infectious Disease Epidemic, Article 93 of the Law No 6 of 2018 Concerning of Health Quarantine, and Criminal Code, especially Article 212216, Article 335-336 of Criminal Core, and the addition of a Telegram Letter of the National Police Chief No. ST/16/18/VI/Ops.2/2020 of June 5 2020, which encourages all hospitals to carry out the swab/PCR test for the referred patient and who show symptoms of Covid-19 and have a history of chronic disease, or are in critical condition. However, in practice, these laws and regulations have not been implemented optimally and so far, have not been implemented directly to the perpetrators.

2. The limitation of security on several hospitals at Jayapura which made the forcibly picked up covid19 infected patient corpse happened. The powerlessness of health workers in facing pressure and threats from the family or communities that are impatient for the test result and tend to impose their will by forcing themselves to take the corpse from the hospital. The limited number of officers carrying out security duties in the related covid-19 places cemeteries and hospitals. The aim is to provide a sense of security to the medical staff at the hospital, and at the same time to prevent cases of forcibly picking up the corpse of the covid-19 infected patient. Meanwhile, security at the cemetery is carried out to prevent the public from rejecting the burial of covid-19 bodies.

3. The hospital's limitation of facilities and infrastructure to accommodate and treat the infected patient with covid-19 is still minimal. In addition, the facilities and infrastructure owned by the police, Covid19 Task Force Officer and Civil Service Police Task Force (Satpol PP) are also limited, and are constrained by procedures that must be obeyed by Papua Civil Service Police Task Force as stated by the Law No. 30 of 2014 concerning of Government Administration, The Law No. 8 of 1981 concerning of Criminal Procedure Code, General Principles of Good Governance. Pratap or Standard Operating Procedures (SOP) in the Minister of Internal Affairs No. 54 of 2011 concerning of Standard Operating Procedures (SOP) for Civil Service Police Unit (Satpol PP) in the enforcement of Regional Regulations.

4. The lack of public knowledge about the dangers of the Covid-19 virus is caused of the forcibly picked up covid-19 infected patients and rejection of the burial of covid-19 corpses. The general lack of understanding of the danger of covid-19 coupled with the presence of people who are provoking and imposing their will have led to forcibly picked up and rejection of covid-19 corpses. In addition, the lack of socialization by the central and regional governments and other stakeholders has caused citizens to tend to act in their way, making it increasingly difficult to prevent and reduce the spread of covid-19 at Jayapura.

5. The existence of bad habits or culture from the communities to comply with strict health protocols, use masks, and keep a distance make it increasingly difficult to overcome the problem of covid-19 spread at Jayapura. It's not decreasing, but the positive cases are increasing. The cultural diversity prevailing in the community will affect the value of obedience and the legal compliance of others. Therefore, a high level of legal awareness and compliance is needed for citizens so that the law can be used as a means to maintain harmony in life and order in society.

\section{Conclusion}

From the explanation above it can be concluded that the strategic form of criminal law policy enforcement which taken to prevent and overcome regarding forced picking up the covid-19 infected patient corpse at hospital on this pandemic are using a persuasive approach, negotiation to the late family, and to several resident which refuses to evacuate the covid-19 infected corpse through the road around the late house. So far, the police officer and covid-19 task force didn't implement a criminal law policy against the 
perpetrators of forcibly picking up covid-19 infected corpses and rejecting the burial of covid-19 corpses. The primary consideration is that the family and community members should be buried according to health protocol, finally agreed and allowed according to the applicable regulations. Some of the obstacles faced by the hospital officers and police officers are the legal substance which still overlapped in its implementation; limited security, powerlessness of health officer in facing the pressure and threat, limited number of officers; limited facility and infrastructure owned by the hospital, police officers, and covid-19 task force; lack of public knowledge and understanding regarding the dangers of covid-19, the lack of socialization; and the habit of the people who are not following the strict health protocol, not being disciplined in using mask, and not keeping distance.

\section{References}

Akub, Syukri dan Baharuddin Badaru, Wawasan Due Process of Law Dalam Sistem Peradilan Pidana, Rangkang Education, Yogyakarta, 2013.

Budiyanto, Revitalisasi Peradilan adat Sebagai Alternatif Penyelesaian Delik Adat Pada Masyarakat Hukum Adat Papua, Intelegensia Media, Malang, 2017.

Haryoto, Edie, Agus Pambagio, \& Safira Wasiat, Kebijakan Publik Penanggulangan Covid-19, RMBOOKS PT. Semesta Rakyat Merdeka, Jakarta, 2020.

Saptono, Ade, Pokok-pokok metodologi Penelitian Hukum Empiris Murni Sebuah Alternatif, Penerbit Universitas Tri sakti, Jakarta, 2009.

Ridhoi, M, (2020, April 22). Kriminalitas Meningkat Selama Pandemi Corona, Sebanyak Apa?. Kata Data. https://katadata.co.id/muhammadridhoi/berita/5e9ffbc527b98/kriminalitas-meningkat-selamapandemi-corona-sebanyak-apa

Administrator. (2020, Juni 13). Proses Hukum Pengambil Paksa Jenazah. Media Indonesia. https://mediaindonesia.com/editorials/detail_editorials/2034-proses-hukum-pengambil-paksa-jenazah

Tarmizi, T. (2020, April 19). Melihat sisi hukum penolakan jenazah COVID-19. Antara News. https://www.antaranews.com/berita/1430804/melihat-sisi-hukum-penolakan-jenazah-covid-19

\section{Copyrights}

Copyright for this article is retained by the author(s), with first publication rights granted to the journal.

This is an open-access article distributed under the terms and conditions of the Creative Commons Attribution license (http://creativecommons.org/licenses/by/4.0/). 